\title{
Prevalence Of The Emotional (Emo) Subculture Among University Students In Saudi Arabia
}

\author{
Latifah Ashaalan, Princess Nora Bint Abdulrahman University, Saudi Arabia \\ Aljawharh Alsukah, Princess Nora Bint Abdulrahman University, Saudi Arabia \\ Nourah Abdulrhman Algadheeb, Princess Nora Bint Abdulrahman University, Saudi Arabia
}

\begin{abstract}
This research aimed to identify the prevalence of the emotional (emo) subculture among students at Princess Noura bint Abdulrahman University (PNU), Saudi Arabia, and to detect differences in emo behavior and orientation among university departments and academic levels. A questionnaire assessing emo behavior/orientation was developed and self-administered by 1275 PNU students in various departments. The questionnaire's sincerity and persistence were verified. The mean overall score (1.64), and Compared with the general average (4), indicated that the emo subculture was not prevalent among PNU students. Mean scores were highest in the emotions domain (2.21), followed by beliefs (1.58), behavior (1.46), and general appearance (1.26). Mean overall scores were higher in the arts department than in other academic departments and in lower academic levels.
\end{abstract}

Keywords: Emo; Saudi University Students; Saudi Arabia

\section{INTRODUCTION}

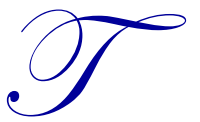

he emo subculture, which appeared among adolescents and young people in Western societies and has spread by acculturation throughout most of the world, has drawn the attention of researchers in the field. The term "emo" is an abbreviation of the word "emotion". This subculture originated within the punk rock movement of the early 1980s; "emo" originally referred to a genre of rock music characterized by lyrics focusing on pain, sadness, pessimism, and despair (Phillipov, 2010). The term has evolved in the last decade to represent a way of life characterized by specific forms of dress, behavior, and thinking.

The 2007 suicides of three emo girls in Australia made researchers aware of the seriousness of the emo phenomenon. An opinion poll found that "emo" ranked fourth on a list of words appearing on the Internet that caused parents to fear for their children (Johnson, 2008). Emo has been associated with antisocial behaviors such as withdrawal and isolation, theft, and drug abuse (Baker \& Bor, 2008; Mazzaferro, 2010), as well as with suicidal thoughts, suicide attempts, and self-harm, including self-wounding, slash-and-burn self-mutilation, abrasion, and biting (Phillipov, 2010; Lim, 2007).

The proportion of young people is increasing in Saudi Arabia; they currently comprise $60 \%$ of the population. This segment of the population, especially those in university environments, is strongly associated with recent and ongoing cultural movements and socioeconomic changes. Explosive growth in the number of Internet users in Saudi Arabia (11.4 million), most of whom are young, has exposed many individuals to new forms of behavior and ideas, such as emo, within the context of media-based cultural contact. Such exposure has contributed to friction due to cultural differences. Most (90\%) users have said that the Internet is an essential part of their personal lives (Report Communications and Information Technology, 2010). 
In an investigation of the emo subculture in Saudi society, reporters from the Saudi Gazette met several young people who spoke about their experiences with self-harm and suicide attempts (As-Sulaimi, 2012). Within this context, this study aimed to identify the extent to which emo behavior and orientations have spread among students at Princess Noura bint Abdulrahman University (PNU), Riyadh, Saudi Arabia, and to detect differences in emo behavior/orientation among academic departments and levels.

\section{METHODS}

For this study, a self-assessment questionnaire to assess emo behavior/orientation was developed on the basis of 28 words associated with emo (Table 1). The questionnaire included four dimensions: general appearance, behavior, beliefs, and emotions. Respondents rated the frequency with which they experienced each item on a fourpoint scale ranging from never (1) to always (4). The internal consistency of the questionnaire, interdependence of items, and ability of items to measure the intended attributes were verified. Cronbach's alpha coefficients for the general appearance (0.87), behavior (0.65), beliefs (0.86), and emotions $(0.90)$ domains, as well as for the instrument overall (0.94), indicated satisfactory to high reliability.

A total of 1275 PNU students in various departments and academic levels in the fields of science, health, and the humanities completed the questionnaire online between 15 March and 10 April 2012. Response rates were highest among students in the education department (25\%) and those in the fifth academic level (37\%), and lowest among those in pharmaceutical studies (1.4\%) and the second academic level (1.6\%).

Table 1: Results of a Self-Administered Questionnaire Assessing the Main Components of the Emo Subculture Among University Students in Saudi Arabia

\begin{tabular}{|c|c|c|c|c|c|c|c|}
\hline \multirow{2}{*}{$\begin{array}{l}\text { Domain/ } \\
\text { Item }\end{array}$} & \multirow{2}{*}{ Statement } & \multicolumn{4}{|c|}{ Responses $n(\%)$} & \multirow{2}{*}{$\begin{array}{c}\text { Average Mean } \\
\text { Score (SD) }\end{array}$} & \multirow{2}{*}{ Rank } \\
\hline & & Never & Rarely & Sometimes & Always & & \\
\hline $\begin{array}{l}\text { General } \\
\text { appearance }\end{array}$ & $\begin{array}{l}\text { Regarding my general } \\
\text { appearance, I tend to: }\end{array}$ & & & & & 1.26 & \\
\hline 1 & $\begin{array}{l}\text { Wear black with pink } \\
\text { accents. }\end{array}$ & $388(30.4)$ & $356(27.9)$ & $452(35.5)$ & $79(6.2)$ & $2.17(0.94)$ & 1 \\
\hline 2 & Dye my hair black. & $912(71.5)$ & $167(13.1)$ & $119(9.3)$ & $77(6.0)$ & $1.50(0.89)$ & 2 \\
\hline 3 & $\begin{array}{l}\text { Dye some tufts of hair a } \\
\text { bright color, such as } \\
\text { fuchsia or blue. }\end{array}$ & $1239(97.2)$ & $19(1.5)$ & $13(1.0)$ & $4(0.3)$ & $1.04(0.29)$ & 9 \\
\hline 4 & Wear an eyebrow ring. & $1255(98.4)$ & $3(0.2)$ & $11(0.9)$ & $6(0.5)$ & $1.03(0.28)$ & 11 \\
\hline 5 & Wear a lip ring. & $1250(98.1)$ & $10(0.8)$ & $8(0.6)$ & $7(0.5)$ & $1.04(0.28)$ & 9 \\
\hline 6 & $\begin{array}{l}\text { Thickly apply black } \\
\text { eyeliner. }\end{array}$ & $899(70.5)$ & 177 (13.9) & $152(11.9)$ & $47(3.7)$ & $1.49(0.84)$ & 3 \\
\hline 7 & $\begin{array}{l}\text { Use red or fuchsia eye } \\
\text { shadow. }\end{array}$ & $1150(90.2)$ & $63(4.9)$ & $55(4.3)$ & $7(0.5)$ & $1.15(0.50)$ & 4 \\
\hline 8 & $\begin{array}{l}\text { Wear clothes or } \\
\text { accessories depicting } \\
\text { skulls and skeletons. }\end{array}$ & $1176(92.2)$ & $57(4.5)$ & $34(2.7)$ & $8(0.6)$ & $1.12(0.44)$ & 6 \\
\hline 9 & $\begin{array}{l}\text { Wear metal accessories } \\
\text { with sharp points. }\end{array}$ & $1206(94.6)$ & $47(3.1)$ & $19(1.5)$ & $3(0.2)$ & $1.07(0.34)$ & 8 \\
\hline 10 & $\begin{array}{l}\text { Wear T-shirts bearing } \\
\text { the names of rock songs. }\end{array}$ & $1149(90.1)$ & $79(6.2)$ & $36(2.8)$ & $11(0.9)$ & $1.14(0.48)$ & 5 \\
\hline 11 & $\begin{array}{l}\text { Wear T-shirts depicting } \\
\text { rock musicians. }\end{array}$ & $1189(93.3)$ & $49(3.8)$ & $28(2.2)$ & $9(0.7)$ & $1.10(0.43)$ & 7 \\
\hline Behavior & I do or have done: & & & & & 1.46 & \\
\hline 12 & $\begin{array}{l}\text { Attempt(ed) to injure my } \\
\text { hand. }\end{array}$ & $1194(93.6)$ & $48(3.8)$ & $24(1.9)$ & $9(0.7)$ & $1.10(0.41)$ & 3 \\
\hline 13 & Isolate(d) myself. & $752(59.0)$ & $242(19.0)$ & $237(18.6)$ & $44(3.5)$ & $1.67(0.90)$ & 1 \\
\hline 14 & $\begin{array}{l}\text { Alleviate(d) my pain by } \\
\text { listening to music. }\end{array}$ & $792(62.1)$ & $235(18.4)$ & $192(15.1)$ & $56(4.4)$ & $1.62(0.90)$ & 2 \\
\hline Beliefs & I wonder about or think: & & & & & 1.58 & \\
\hline 15 & Life is useless. & $921(72.2)$ & $219(17.2)$ & $117(9.2)$ & $18(1.4)$ & $1.40(0.71)$ & 4 \\
\hline 16 & $\begin{array}{l}\text { Suicide might be a } \\
\text { solution. }\end{array}$ & $1137(89.2)$ & $83(6.5)$ & $40(3.1)$ & $15(1.2)$ & $1.16(0.52)$ & 5 \\
\hline
\end{tabular}


Table 1 cont.

\begin{tabular}{|c|c|c|c|c|c|c|c|}
\hline \multirow{2}{*}{$\begin{array}{l}\text { Domain/ } \\
\text { Item }\end{array}$} & \multirow{2}{*}{ Statement } & \multicolumn{4}{|c|}{ Responses $n(\%)$} & \multirow{2}{*}{$\begin{array}{c}\text { Average }{ }^{*} \text { Mean } \\
\text { Score (SD) } \\
\end{array}$} & \multirow{2}{*}{ Rank } \\
\hline & & Never & Rarely & Sometimes & Always & & \\
\hline 17 & $\begin{array}{l}\text { The world is } \\
\text { characterized by } \\
\text { injustice and cruelty. }\end{array}$ & $658(51.6)$ & $316(24.8)$ & $235(18.4)$ & $66(5.2)$ & $1.77(0.93)$ & 2 \\
\hline 18 & $\begin{array}{l}\text { People do not understand } \\
\text { me. }\end{array}$ & $440(34.5)$ & $373(29.3)$ & $353(27.7)$ & $109(8.5)$ & $2.10(0.98)$ & 1 \\
\hline 19 & People are persecuted. & $888(69.6)$ & $236(18.5)$ & $112(8.8)$ & $39(3.1)$ & $1.45(0.78)$ & 3 \\
\hline Emotions & Ifeel: & & & & & 2.21 & \\
\hline 20 & Loneliness. & $478(37.5)$ & $373(29.3)$ & $350(27.5)$ & $74(5.8)$ & $2.02(0.94)$ & 7 \\
\hline 21 & Sadness and depression. & $428(33.6)$ & $444(34.8)$ & $365(28.6)$ & $38(3.0)$ & $2.01(0.86)$ & 8 \\
\hline 22 & Shyness. & 238 (18.7) & 309 (24.4) & $540(42.4)$ & $188(14.7)$ & $2.53(0.96)$ & 1 \\
\hline 23 & Frustration. & $385(30.2)$ & $444(34.8)$ & $378(29.6)$ & $68(5.3)$ & $2.10(0.90)$ & 5 \\
\hline 24 & Pessimism. & $618(48.5)$ & $382(30.0)$ & $235(18.4)$ & $40(3.1)$ & $1.76(0.86)$ & 9 \\
\hline 25 & That I want to cry. & $211(16.5)$ & $375(29.4)$ & $542(42.5)$ & $147(11.5)$ & $2.49(0.90)$ & 2 \\
\hline 26 & $\begin{array}{l}\text { That I have a broken } \\
\text { heart. }\end{array}$ & $490(38.4)$ & $340(26.7)$ & $323(25.3)$ & $122(9.6)$ & $2.06(1.1)$ & 6 \\
\hline 27 & Sensitive and easily hurt. & $324(25.4)$ & $317(24.9)$ & $366(28.7)$ & $268(21.0)$ & $2.45(1.09)$ & 4 \\
\hline 28 & Hidden anger. & $303(23.8)$ & $317(24.9)$ & $419(32.9)$ & $236(18.5)$ & $2.46(1.05)$ & 3 \\
\hline
\end{tabular}

$\mathrm{SD}$, standard deviation.

\section{Statistical Analysis}

Frequencies and percentages of questionnaire responses were calculated, and means and standard deviations of item and domain scores were determined. Analyses of variance were performed to identify differences in variables.

\section{RESULTS AND DISCUSSION}

\section{General Appearance}

Mean item scores in the general appearance domain of the questionnaire ranged from 1.03 to 2.17 (mean domain score, 1.26), and comparing average after a year (4), indicating that general appearance components of the emo subculture were not prevalent among PNU students (Table 1).

\section{Behavior}

Mean item scores in the behavior domain ranged from 1.10 to 1.67 (mean domain score, 1.46), and comparing the average after a year (4), indicating that emo behavior was not prevalent among PNU students (Table 1). Although all scores in this domain were low, they were highest for item 13 (isolation) and nearly as high for item 14 (alleviate pain by listening to music). These results can interpreted in seclusion esteem, as a tendency to converge is characteristic of university-aged individuals. Psychologists have confirmed that tendencies for introversion and isolation are typical in adolescents (Dacey \& Kenny, 1994), as evidenced by multiple behavioral patterns such as withdrawal and expressing one's views by writing personal notes. Furthermore, music plays a role in contemporary life among young people in Saudi Arabia, especially given the cultural openness of the society, and is marketed as a way to alleviate pain and suffering through traditional media and modern means using psychological tactics and propaganda. Several studies conducted in other countries found that music improved mood among adolescents (Ashley \& Durbin, 2006; Gold, Voracek, \& Wigram, 2004).

Item 12 (self-injury of hand) yielded the lowest mean score in the behavior domain. Deliberate self-harm is associated with some mental disorders, and either factors property such as assimilation high behavior of some currents Kalaimo; these factors do not apply to the research sample. 


\section{Beliefs}

Mean item scores in the beliefs domain ranged from 1.16 to 2.10 (mean domain score, 1.58), and by comparing the general average, (4) it is clear that Undecided Emo's beliefs are weak and limited among PNU students (Table 1). Although all scores in this domain were low, they were highest for item 18 ("people do not understand me"). This result reflects the suffering experienced by adolescents, who desire independence and look forward to the future, but have limited experience in taking control of their own lives, resulting in conflicts with the views of others. Especially in Saudi and other Arabic societies, conservative views emphasize paternal authority. This finding is in agreement with the results of many studies examining the importance of independence in the development of adolescents (Fuligni, 1998; Phinney et al., 2005; Smetana et al. 2006). Smetana et al. (2006) discussed the conflict that arises in adolescents when trying to prove the independence of their personalities and views, which exacerbates familial relationships.

Item 16 (consideration of suicide) yielded the lowest mean score in the beliefs domain. Suicidal thoughts are considered to be extreme and are associated with severe mental disorders, such as depression. Such thoughts are also prohibited (haraam) in Islam. The results of this study differ from those of others in which an association between suicidal thoughts and emo orientation has been observed (Phillipov, 2010; Lim, 2007). Moreover, other studies have found that many young people confined affected by emo and the external form (Bailey, 2005).

\section{Emotions}

Mean item scores in the emotions domain ranged from 1.76 to 2.53 (mean domain score, 2.21), and comparing the general average (4) it is clear that after emotions of EMO average among university students. Item 22 (shame) yielded the highest mean score in this domain, reflecting this emotional attribute's association with adolescents' psychological development, especially within the context of the limited social opportunities available in Saudi society to interact in the relations between personal public and collective participation. This result confirms the findings of Sakuragi (2004) and Jackson et al. (2000) that feelings of shame were more prevalent among university students than children.

\section{Prevalence of the Emo Subculture among University Students}

To determine the prevalence of the emo subculture among PNU students, frequencies and percentages of domain scores were classified according to the degree of emo affiliation (none, low, medium, high; Table 2). The distributions of scores in the general appearance, behavior, and beliefs domains reflected a very low degree of emo orientation, and that in the emotions domain indicated a low degree of affiliation with the emo subculture. The highest percentage of scores reflecting a high degree of emo affiliation was found in the emotions domain (6.4\%), and the lowest percentage was found in the general appearance domain $(0.2 \%)$. These results indicate that a maximum of $0.2 \%$ of respondents, a very low proportion, showed a high degree of affiliation with the emo subculture in all domains.

Table 2. Prevalence of Emo Orientation among 1275 University Students in Saudi Arabia, According to Distributions of Domain Scores

\begin{tabular}{|c|c|c|c|c|}
\hline \multirow{2}{*}{$\begin{array}{c}\text { Degree of Emo } \\
\text { Affiliation }\end{array}$} & \multicolumn{4}{|c|}{ Proportion of Scores $n(\%)$} \\
\hline & General Appearance & Behavior & Beliefs & Emotions \\
\hline None & $1218(95.5 \%)$ & $997(78.2 \%)$ & $845(66.3 \%)$ & $344(27.0 \%)$ \\
\hline Low & $50(3.9 \%)$ & $200(15.7 \%)$ & $321(25.2 \%)$ & $462(36.3 \%)$ \\
\hline Medium & $4(0.3 \%)$ & $61(4.8 \%)$ & $81(6.4 \%)$ & $387(30.4 \%)$ \\
\hline High & $3(0.2 \%)$ & $17(1.3 \%)$ & $28(2.2 \%)$ & $81(6.4 \%)$ \\
\hline
\end{tabular}

Differences in emo orientation among academic departments were also analyzed. Significant differences among departments were found in total scores and those of all domains except behavior (Tables 3, 4). Mean total scores and those in the appearance, beliefs, and emotions domains were higher among students in the art department and in the undefined category than among those in several other departments (Table 4). Students in the nursing department had higher scores than those in other departments in the beliefs domain, and emotions domain scores were higher among students in the science department (Table 4). The consistently higher scores among art students 
may be due to the size of this department at PNU (9000 students), which may exceed the capacity of psychological counseling services, contributing to the emergence of some forms unwanted behavior. In addition, the admission standards of this department are considered to be lower than those of many other departments at PNU; the presence of undesirable behavior may be related to reduced levels of scientific and academic proficiency.

Table 3. Variation in Domain and Total Scores among Academic Departments

\begin{tabular}{|c|c|c|c|c|}
\hline Domain & Source of Variation (df) & Sum of Squares (mean) & $\boldsymbol{P}$ & Significance Level \\
\hline General appearance & $\begin{array}{c}\text { Among groups (12) } \\
\text { Within group (1262) }\end{array}$ & $\begin{array}{c}1.76(0.15) \\
103.8(0.08)\end{array}$ & 1.78 & $0.046^{*}$ \\
\hline Behavior & $\begin{array}{l}\text { Among groups (12) } \\
\text { Within group (1262) }\end{array}$ & $\begin{array}{c}4.10(0.34) \\
419.68(0.33)\end{array}$ & 1.03 & 0.420 \\
\hline Beliefs & $\begin{array}{l}\text { Among groups (12) } \\
\text { Within group (1262) }\end{array}$ & $\begin{array}{c}10.64(0.89) \\
460.28(0.37)\end{array}$ & 2.43 & $0.004 * *$ \\
\hline Emotions & $\begin{array}{l}\text { Among groups (12) } \\
\text { Within group (1262) }\end{array}$ & $\begin{array}{c}12.67(1.06) \\
631.34(0.50)\end{array}$ & 2.11 & $0.014 *$ \\
\hline Total & $\begin{array}{l}\text { Among groups (12) } \\
\text { Within group (1262) }\end{array}$ & $\begin{array}{c}4.79(0.40) \\
212.16(0.17) \\
\end{array}$ & 2.37 & $0.005 * *$ \\
\hline
\end{tabular}

Table 4. Differences in Emo Orientation among University Students in Different Departments

\begin{tabular}{|c|c|c|c|c|c|}
\hline \multirow{2}{*}{ Department } & \multicolumn{5}{|c|}{ Mean Score } \\
\hline & General Appearance & Behavior & Beliefs & Emotions & Total \\
\hline Science & $1.25^{\mathrm{a}, \mathrm{b}}$ & & $1.57^{\mathrm{e}}$ & $2.27^{\mathrm{f}}$ & $1.65^{j}$ \\
\hline Education & $1.25^{\mathrm{a}, \mathrm{b}}$ & & $1.51^{\mathrm{c}, \mathrm{e}}$ & $2.20^{\mathrm{g}}$ & $1.62^{\mathrm{i}, \mathrm{j}}$ \\
\hline Arts & $1.31^{\mathrm{a}}$ & & $1.68^{\mathrm{c}, \mathrm{e}}$ & $2.33^{\mathrm{g}}$ & $1.72^{\mathrm{i}}$ \\
\hline Business administration & $1.23^{\mathrm{a}, \mathrm{b}}$ & & $1.44^{\mathrm{c}, \mathrm{d}, \mathrm{e}}$ & $2.04^{\mathrm{f}, \mathrm{g}, \mathrm{h}}$ & $1.55^{\mathrm{i}, \mathrm{j}}$ \\
\hline Art and design & 1.28 & & $1.50^{\mathrm{e}}$ & 2.13 & $1.59^{\mathrm{j}}$ \\
\hline Languages and translation & $1.22^{\mathrm{a}, \mathrm{b}}$ & & $1.55^{\mathrm{e}}$ & $2.06^{\mathrm{f}, \mathrm{g}, \mathrm{h}}$ & $1.58^{\mathrm{i}, \mathrm{j}}$ \\
\hline MIS & $1.23^{\mathrm{b}}$ & & $1.50^{\mathrm{c}, \mathrm{e}}$ & 2.16 & $1.60^{\mathrm{j}}$ \\
\hline Home economics & $1.20^{\mathrm{b}}$ & & $1.54^{\mathrm{e}}$ & 2.10 & $1.57^{\mathrm{j}}$ \\
\hline Nursing & 1.30 & & $1.72^{d}$ & 2.24 & 1.72 \\
\hline Physiotherapy & $1.22^{\mathrm{a}, \mathrm{b}}$ & & $1.61^{\mathrm{e}}$ & $2.07^{\mathrm{g}, \mathrm{h}}$ & $1.60^{\mathrm{j}}$ \\
\hline Pharmaceutical studies & 1.26 & & $1.48^{\mathrm{e}}$ & 2.28 & 1.64 \\
\hline Social services & $1.24^{\mathrm{b}}$ & & $1.62^{\mathrm{e}}$ & 2.12 & $1.60^{\mathrm{j}}$ \\
\hline Undefined & $1.38^{\mathbf{b}}$ & & $1.89^{\mathrm{e}}$ & $2.41^{\mathrm{h}}$ & $1.83^{\mathbf{j}}$ \\
\hline
\end{tabular}

Superscripted letters indicate significant differences (least significant difference test, $P<\mathrm{xx}$ ) among departments, with significantly higher scores in bold.

Analysis of differences in the results according to academic level revealed significant differences in total and all domain scores (Table 5, 6). All scores were significantly higher among students in levels $1-4$, representing the first two years of undergraduate study (Table 6). These students were likely younger than those in higher levels and had less experience in the university environment, which may make them more inclined to some forms of unwanted behavior, such as those assessed in association with emo in this study.

Table 5. Variation in Domain and Total Scores among Academic Levels

\begin{tabular}{|c|c|c|c|c|}
\hline Domain & Source of Variation (df) & Sum of Squares (mean) & $\boldsymbol{P}$ & Significance Level \\
\hline General appearance & $\begin{array}{c}\text { Among groups (2) } \\
\text { Within group (1263) }\end{array}$ & $\begin{array}{c}1.25(0.63) \\
103.54(0.08)\end{array}$ & 7.65 & $0.000 * *$ \\
\hline Behavior & $\begin{array}{l}\text { Among groups (2) } \\
\text { Within group (1263) }\end{array}$ & $\begin{array}{c}2.41(1.21) \\
416.84(0.33)\end{array}$ & 3.65 & $0.026^{*}$ \\
\hline Beliefs & $\begin{array}{l}\text { Among groups (2) } \\
\text { Within group (1263) }\end{array}$ & $\begin{array}{c}6.88(3.44) \\
457.24(0.36)\end{array}$ & 9.51 & $0.000 * *$ \\
\hline Emotions & $\begin{array}{l}\text { Among groups (2) } \\
\text { Within group (1263) }\end{array}$ & $\begin{array}{c}3.11(1.55) \\
634.74(0.50)\end{array}$ & 3.09 & $0.046^{*}$ \\
\hline Total & $\begin{array}{l}\text { Among groups (2) } \\
\text { Within group (1263) }\end{array}$ & $\begin{array}{c}2.69(1.35) \\
212.30(0.17)\end{array}$ & 8.01 & $0.000 * *$ \\
\hline
\end{tabular}

$* P<0.05, * * P<0.01$. df, degrees of freedom. 
Table 6. Differences in Emo Orientation among University Students at Different Academic Levels

\begin{tabular}{|c|c|c|c|c|c|}
\hline \multirow{2}{*}{ Academic Level } & \multicolumn{5}{|c|}{ Mean Score } \\
\hline & General Appearance & Behavior & Beliefs & Emotions & Total \\
\hline $1-4$ & $1.34^{\mathrm{a}}$ & $1.56^{\mathrm{b}}$ & $1.76^{\mathrm{a}}$ & $2.33^{\mathrm{b}}$ & $1.75^{\mathrm{a}}$ \\
\hline $5-6$ & 1.26 & 1.46 & 1.57 & 2.21 & 1.64 \\
\hline $7-10$ & 1.24 & 1.42 & 1.52 & 2.17 & 1.61 \\
\hline
\end{tabular}

\section{CONCLUSION}

Despite the high proportion of youth in Saudi society and increasing cultural openness in the last two decades, which have led to increases in the number of Internet users and those traveling abroad, the emo subculture is not prevalent among female university students in Saudi Arabia. This finding may be explained by the cultural emphasis on parental authority and the influence of conservative cultural and religious norms, which reduce the prevalence of Western ideas among adolescents and young people. Similar studies focusing on middle- and highschool students (aged 13-17 years) in Saudi Arabia would aid comparison with Western studies.

\section{AUTHOR INFORMATION}

Dr. Latifah Ashaalan, the associate professor of Psychology has been a member of the Saudi parliament (Majlis Alshura) since January, 2013. Dr. Ashaalan has obtained her MSc degree in Health Psychology from the University of Surrey, England, and her PhD degree in Counseling Psychology in 2004 from Princess Nourah Bint Abdulrahman University, Saudi Arabia. Dr. Ashaalan is a member of Canadian Psychological Association, the Egyptian Psychologists Association, Saudi Psychiatric Association and The Saudi Educational and Psychological Association. E-mail: shaalan1@shura.gov.sa or lat-ashaalan@hotmail.com

Dr. Aljawharh Alsukah is an Assistant Professor of Psychology at the Princess Nourah Bint Abdulrahman University in Riyadh, Kingdom of Saudi Arabia. Dr. Alsukah has a B.A. in Education (1991), M.A. degree in Developmental \& Educational Psychology (2000), and a Ph.D. in Psychology (2008). Dr. Alsukah is a member of the American Psychological Association (APA) and the Saudi Educational and Psychological Association. Dr. Alsukah is currently the Director of the External Joint Supervision Programme and has been since 2012. Dr. Alsukah was the Director of Preschool and Kindergarten at the College of Education from 2004-2006 and the Director of Counseling And Guidance Office at the College of Education PNU from 2007-2009. E-mail: aialsogeh@pnu.edu.sa or alsukeh@ hotmail.com (Corresponding author)

Dr. Nourah Abdulrhman Algadheeb is an Assistant Professor of Psychology at the Princess Nourah Bint Abdulrahman University in Riyadh, Kingdom of Saudi Arabia. Dr. Algadheeb has a B.A. in Special Education from King Saud University (1995), M.A. degree in Psychological Measurement and Evaluation from King Saud University (2002), and a Ph.D. in Psychology from Nourah Bint Abdulrahman University (2008). Dr. Algadheeb is a member of the Saudi society for Psychological Measurement, Saudi Educational and Psychological Association, Egyptian Association for Psychological Studies, and Saudi Psychiatric Association. Dr. Algadheeb was the Deputy Head of the Talented Students Section at the Faculty of Education from 2007-2009 and Head of the Department of Education and Psychology from 2009-2011. E-mail: naalgdeb@pnu.edu.sa

\section{REFERENCES}

1. CITC information. (2010). Information Technology Report on the online system in Saudi Arabia. Available in www.citc.gov.sa

2. As-Sulaimi, KM. (2012 May 13). The emo subculture invades Saudi society. Saudi Gazette, Retrieved from http://www.saudigazette.com.sa/index.cfm?method=home.regcon\&contentID=2009111054068

3. Ashley, R \& Durbin, E. (2006). Music preference, music listening and mood regulation in preadolescence. Paper presented at 9th International Conference on Music Perception and Cognition, Bologna, Italy.

4. Bailey, B. (2005). Emo music and youth culture. In S. Steinberg, P. Parmar \& B Richard (Eds). Encyclopedia of Contemporary Youth Culture. Westport CT, Greenwood Press. 
5. Baker, F \& Bor, W. (2008). Can music preference indicate mental health status in young people? Australasian Psychiatry, 16(4):248-288.

6. Dacey, J \& Kenny, M. (1994). Adolescent Development. Madison, UK, Braun \& Benchmark.

7. Definis-Gojanovic, M, Gugic, D \& Sutlovic, D. (2009). Suicide and emo youth subculture: A case analysis. Collegium Antropologicum, 33(2):173-175.

8. Gold, B , Voracek, C , \& Wigram, T. (2004). Effects of music therapy for children and adolescents with psychopathology: A meta-analysis. Journal of Child Psychology and Psychiatry, 45 (6):1054-1063.

9. Johnson, B. (2008 August 6). The web's fourth most dangerous word? Emo. The Guardian, Retrieved from http://www.guardian.co.uk/technology/blog/2008/aug/06/thewebsfourthmostdangerous

10. Komsomolets, M. (2006). Moscow teens develop their own emo-culture, worshipping depression and sadness. Retrieved from http://english.pravda.ru/society/stories/19-12-2006/86000-emo_kids-0

11. Lim, C. (2007). The link between self- harm and emo. Retrieved from http://www.helium.com/items/690200-the-link-between-self-harm-and-emo

12. Mazzaferro, VP. (2010). Effects of the emo music genre. Degree Bachelor of Arts, California Polytechnic State University, San Luis Obispo.

13. Phillipov, M. (2010). Generic misery music? Emo and the problem of contemporary youth culture. Media International Australia, 136:60-70.

14. Schmitt, K. (2011). Exploring Dress and Behavior of the Emo Subculture. Master of Arts in American Studies, Kennesaw State University. Retrieved from: http://digitalcommons.kennesaw.edu/etd/465

15. Scott, L \& Chur-Hanson, A. (2008). The mental health literacy of rural adolescents: Emo subculture and SMS texting. ? Australasian Psychiatry, 16(5):359-362.

16. Seganti, F. R. \& Smahel, D. (2011). Finding the meaning of emo in youths .online social networking: A qualitative study of contemporary Italian emo. University of Illinois at Chicago, 16, 7, 20 s. ISSN 13960466. 2011. Retrieved from: http://firstmonday.org/htbin/cgiwrap/bin/ojs/index.php/fm/article/view/3197/3021

17. Sedia, Ekaterina. "Cheer Up Emo Kid: Being Depressed (Or Gay) Is Not All in Your Genes." Clarkesworld Magazine. 2008. http://clarkesworldmagazine.com/sedia 


\section{NOTES}

